\title{
シリーズ“混相流先端技術”
}

\section{超音波パルスのドップラー効果を利用した気泡流動特性計測技術 *}

\section{Ultrasound Pulse Doppler Technique for Flow Measurement in Bubbly Flows}

\author{
有冨正憲 \\ ARITOMI Masanori
}

\begin{abstract}
A measurement system using Doppler method of ultrasound pulses has been developed in order to clarify multi-dimensional flow characteristics of bubbly flows. The measurement system can measure an instantaneous velocity profile of mixture. Since the statistical process of the measured velocity profiles gives information of velocity profiles of both gas and liquid phases, a void fraction profile, turbulence intensity of liquid phase for bubbly flow in a channel, a liquid velocity profile around a bubble and so on. In this paper, the measurement system is discussed and typical results are introduced.
\end{abstract}

Keywords: Measurement system, bubbly flow, Doppler effect of ultrasound pulse, velocity profile, void fraction profile

\section{1. はじめに}

著者らは，超音波パルスのドップラー効果を利 用した気泡流の多次元流動特性を計測できるシス テムを開発している. 同システムは, 計測線方向 の瞬時気液混合流速分布の計測ができ, 計測結果 を統計的に処理することにより，流路内の気液両 相の流速分布，ボイド率分布，連続相である液相 の乱れの強度分布, 並びに, 気泡周りの液相の流 速分布を求めることができる[1]- [3]. 本報では， 同計測システムと代表的な計測例を紹介する.

\section{2. 実験装置}

実験装置の概略をFig.1に示す．作動流体には水 と空気を用いている。実験装置は, 水循環系, 空 気供給系, テスト部, 並びに, 計測系から構成さ れている. 計測系は超音波流速分布計測計（UVP） とCCDカメラ, パソコンから構成されている.
テスト部は $100 \mathrm{mmx} 10 \mathrm{~mm}$ のアクリル製の垂直二 次元流路である. 気泡はテスト部下部に取り付け られたステンレス細管から注入される. 水には超 音波パルスの反射体として直径 $10 \mu \mathrm{m}$ のナイロン パウダーが混入されている.

\section{3. 計測原理とデー夕処理}

流体中の微粒子や気液界面の動きを超音波パル ス波のエコーを测定し，処理することによって瞬 時気液混合速度分布を求める. 一つの超音波セン サーが，超音波パルスを発信させるとともに，反 射波を受信する。超音波センサーは流路壁に対し て $45^{\circ}$ の角度で取り付けられている. 本研究で用い ているUVPの仕様をTable 1に示す。

位置情報はパルス波の発生から反射波の受信ま での時間経過と液体中の音速から求め, 計測線上 の局所速度ベクトルは超音波パルスの周波数と瞬時

*1998.4.15 受付

** 東京工業大学原子炉工学研究所 $\overline{1} 152-8550$ 東京都目黒区大岡山2-12-1 TEL (03) 5734-3063 FAX (03) 5734-2959 


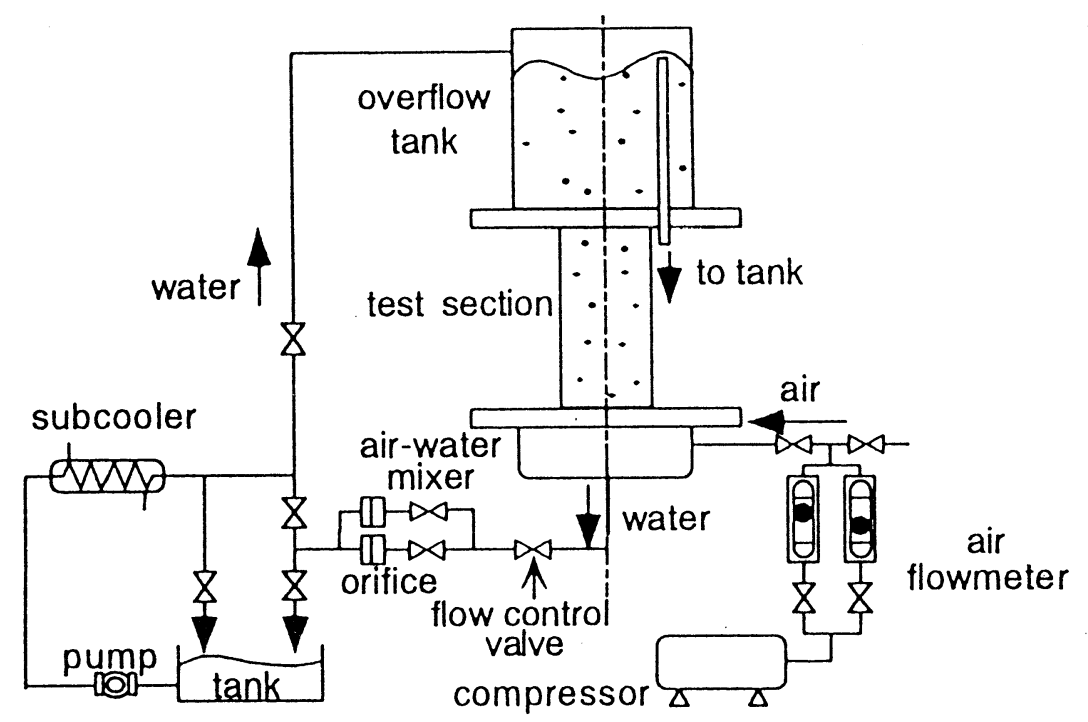

Fig.1 Experimental apparatus

Table 1 Specification of UVP

\begin{tabular}{ll}
\hline Basic ultrasonic frequency & $4 \mathrm{MHz}$ \\
Maximum measurable depth & $758 \mathrm{~mm}$ (variable) \\
Minimum spatial resolution & $0.74 \mathrm{~mm}$ \\
Maximum measurable velocity & $0.75 \mathrm{~m} / \mathrm{s}$ (variable) \\
Velocity resolution & $0.75 \mathrm{~mm} / \mathrm{s}$ (variable) \\
Measurement points & 128 \\
The number of profiles & 1,024 \\
\hline
\end{tabular}

的なドップラー周波数から求められる.

超音波パルス径は5mmであるため，各相の局所 速度分布は統計的に処理して求める必要がある. そこで，9,216回の超音波パルスを発射し，得られ た気液混合速度分布を統計処理する。この計湘に 要する時間は約20分であり，得られた気液混合速 度確率密度分布はこの間の時間平均の分布を示す。

超音波パルスビーム上の計測位置に気泡表面， あるいは，水に混入された微粒子が存在する場合 にはエコーが受信されるが，これらが存在しない 場合には速度データが零として計測されるため, 実際の速度が零の場合と区別できない，そこで， 流速が零のデー夕はその前後の確率密度の平均值 として求め，併せて，デー夕存在確率を求める.

気液混合速度確率密度分布は, 気液両相の速度 確率密度分布の重ね合わせである，そこで，各相 の速度確率密度分布が正規分布であると仮定し， 気液混合速度確率密度分布は，両相の平均流速， 標準偏差, 気液デー夕混合比を 5 つの変数とする
2 つの正規分布の重ね合わせた関数として定義し， 5 つの变数を計測結果と関数形の誤差の自乗が最 小になるように橾り返し計算から求める. 気泡対 向流における気液混合速度確率密度分布の代表的 な測定結果と確率密度関数の比較をFig.2に示す.

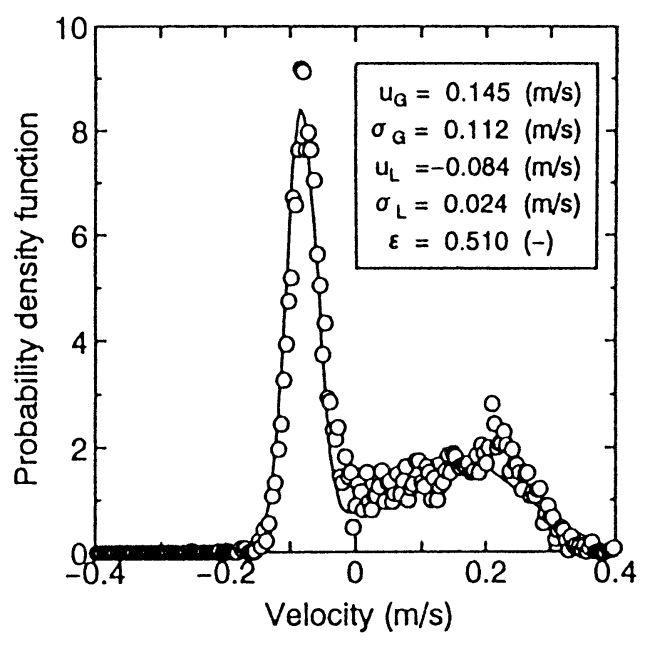

Fig.2 Typical probabilisitic density function of mixture vilocities

4. 計測結果

4. 1 気泡対向流における気液両相の流速分布

低ボイド率条件下の気泡対向流に対して，各計 測位置での気液混合相流速確率密度分布から求めら 


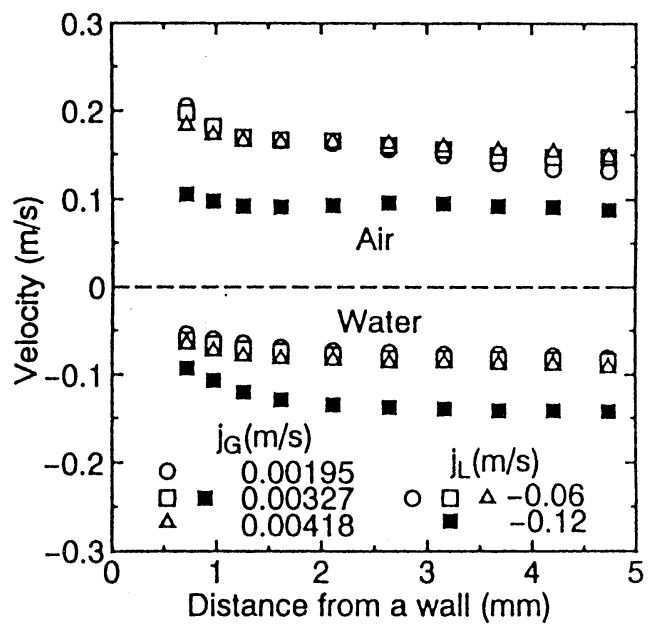

Fig.3 Velocity profiles of both phases in bubbly countercurrent flow

れた気液雨相の平均流速から流路断面内の流速分 布を求めた結果をFig.3に示す．超音波ビーム径は 5mmあり，壁に対して傾けて取り付けているため， 壁近傍での正確な速度データの取得が困難である。 そのため，以降に示す図では計測された速度分布 から壁近彦のデータを削除して示してある.

同図から，水と気泡の流速分布は，共に平坦な 分布ではあるが，壁から流路中心に向かい，水単 相流の場合と同様に增加していること，水の流量 に比べて気泡の流量が空気流量が小さいため，気 泡の流量を変化させても水と気泡の流速分布は殆 ど変化しないこと，更に，水流量が增加すると気 泡の上昇速度は平行して低下することが分かる。 これは，気泡の上昇速度は浮力と界面での抗力と の差により誘起されるためである.

\section{2 気泡対向流のボイド率分布}

気液デー夕混合比にデー夕存在確率を脚けるこ とにより局所気泡存在確率 $\kappa(\mathrm{y})$ を求める. 局所术 イド率 $\alpha(\mathrm{y})$ は， $\kappa(\mathrm{y})$ と比例関係にあると仮定する。 この変換係数は気泡の直径や形状に依存するもの であるが，CCDカメラを用いた画像処理から，流 路断面内で統計平均的にはほぼ一定であることが 判明したので，流路断面内で一定值を仮定する。 そして，画像処理や差圧計測により求めた流路断 面内の平均気泡存在確率と平均ボイド率の比, あ るいは， $u_{8}(y) \cdot \kappa(y)$ の流路断面平均值と見かけの 気泡流量 $\mathrm{j}_{\mathrm{g}}$ との比から変換係数を求めて，局所的な ボイド率 $\alpha(\mathrm{y})$ に変換する.

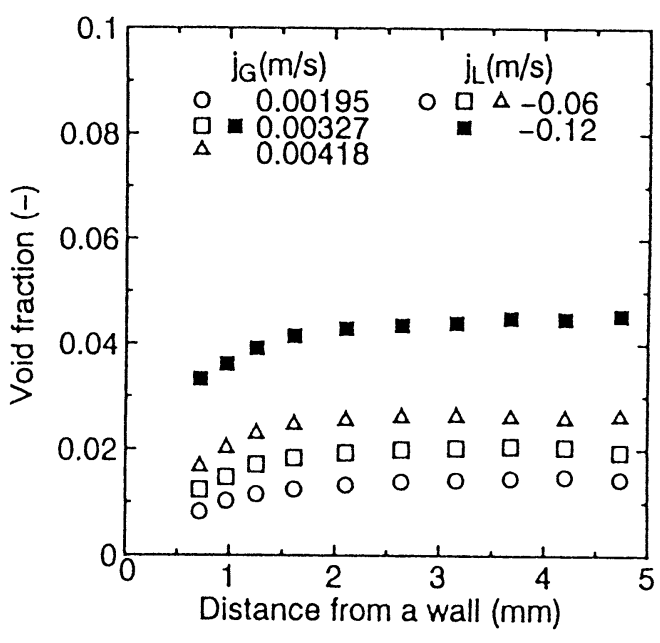

Fig.4 Void fraction profile in bubbly countercurrent flow

ボイド率分布を求めた結果をFig.4に示す。ボイ ド率分布は壁近傍を除くとほほ平坦な分布をして おり，Fig.3に示すように空気流量が增大しても両 相の流速分布は殆ど変化せず，水流量が增加する と下降流速が增大するため気泡の上昇速度は低下 するので，気泡流量と水流量が增加するとボイド 率は增加する。

\section{3 気泡対向流の液相の乱れ強度分布}

気泡流では，気泡によって流れが乱されるため 水単相流の場合と比べて局所的な液相速度の变動 が大きい，そこで，液相の速度変動の標準偏差を 乱れの強さと定義した。そして，気泡の存在によ る乱れの促進効果を調べるために，水単相流の場 合と気泡対向流の場合の液相の速度变動の標準偏 差の比を求め，結果をFig.5に示す，同図から，流 路中央に近づくほど気泡が流れに与える影㫫が強 く現れ，空気流量が大きくなるほど乱れの促進効 果は増大することが分かる。

\section{4 気泡周りの液相の流速分布}

気泡周りの液相の流速分布を求める場合には， 計測された瞬時気液混合流速分布を解析し，気泡 の流速を含む流速分布のみを集め，気泡表面を座 標軸を変換し, 統計処理して流速変動の確率密度 を求める. 気泡表面からの距離をパラメータとし た水流速の確率密度の代表的な結果をFig.6に示す. 同図から，気泡表面では気泡の上昇速度である流 速変動の確率密度分布が, 気泡表面から次第に離 れるに従い，主流部の水流速にピークを持つ確率密 


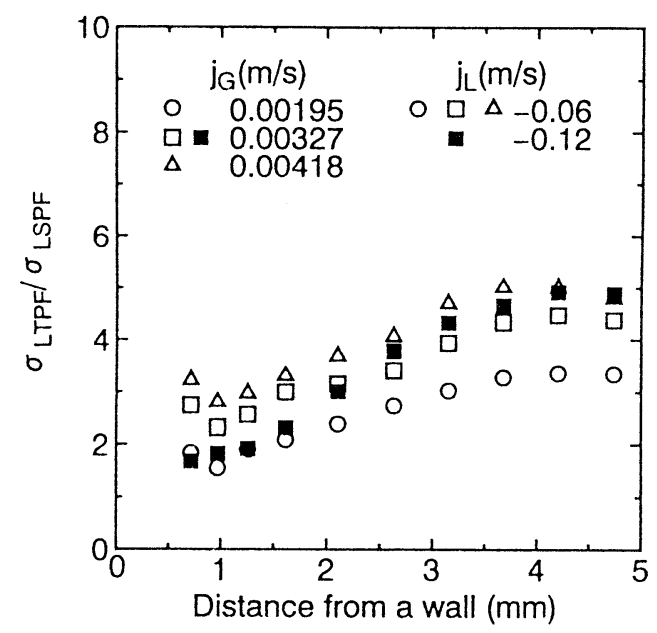

Fig.5 Two-phase multiplier of turbulence intensity of liquid phase in bubbly countercurrent flows

度分布へとシフトしていくことが分かる。

Fig.6に示す流速変動の確率密度分布から各点の 平均流速を求めた気泡周りの流速分布の代表的な 結果をFig.7に示す．気泡表面から $1.5 \mathrm{~mm}$ から $2 \mathrm{~mm}$ 程度の領域では液相の流速分布の勾配は大きく, 気液両相の流量の影響を殆ど受けずに，気泡の上 昇流れが周囲の液相を引き上げて上昇している気 泡境界層となっている。.また, 気泡表面から $5 \mathrm{~mm}$ 程度離れたあたりで流速分布の勾配は再び変化し ており，気泡の上昇流の影響を殆ど受けず，水流量

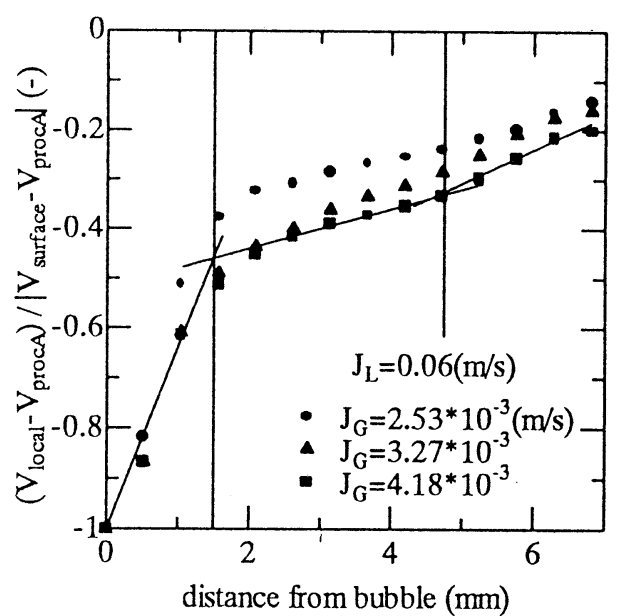

Fig.7 Typical liquid velocity profile around a bubble

の影響を強く受ける主流部となっている。また， この中間の領域は, 気泡の上昇速度と水流量の双 方の影響を受ける遷移領域となっている.

\section{参考文献}

[1] Aritomi, M., et al., J. Nucl. Sci. Technol., Vol.33, 915-923 (1976).

[2] Aritomi, M., et al., J. Nucl. Sci. Technol., Vol.34, 783-791 (1997).

[3] Suzuki, Y., et al., ICONE-6, Paper No.6075, 1-10 (1998.5) (to be published).
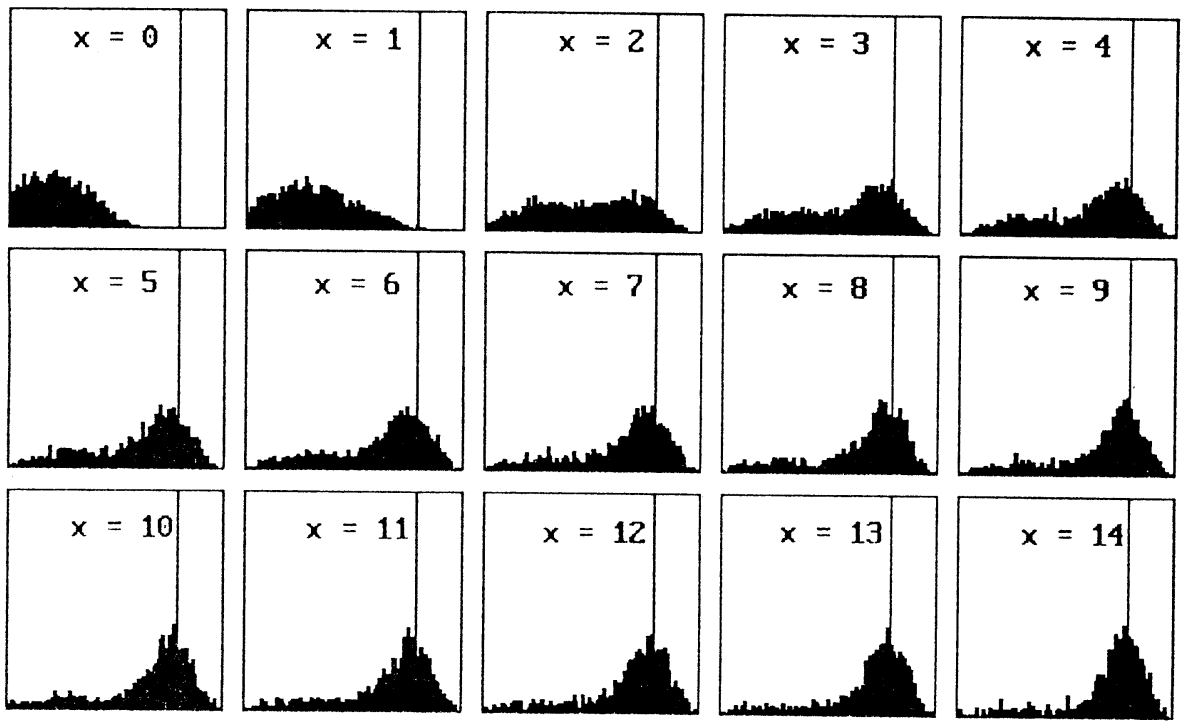

Fig.6 Typical probability density function of liquid velocity profile around a bubble 